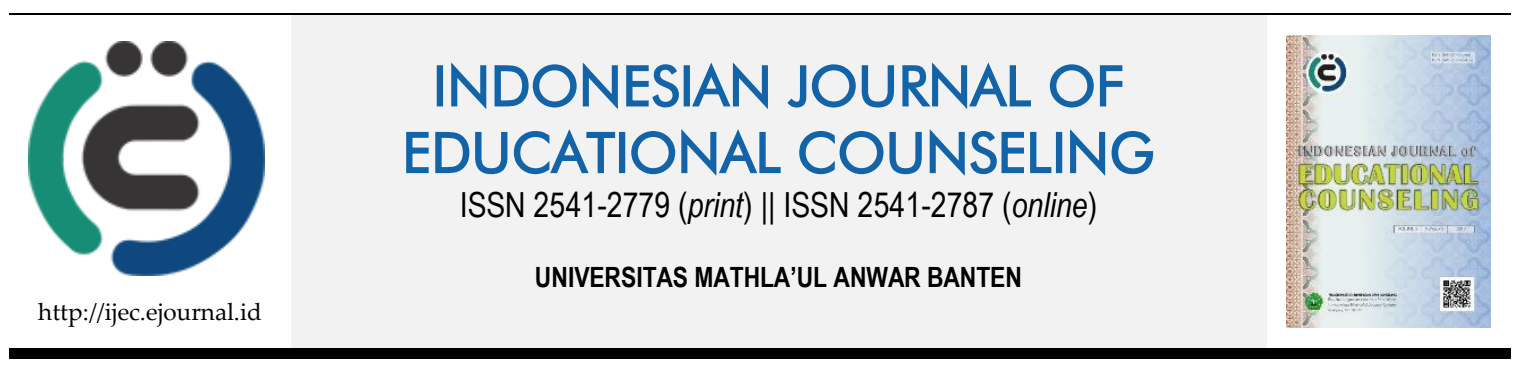

Research Based Article

\title{
Pengembangan Intervensi Konseling Naratif Berbasis Digital dalam Menjawab Tantangan era revolusi Industri 4.0
}

\author{
Amdani Sarjun ${ }^{1}$, Anisa Mawarni² \\ 1, 2 Universitas Islam Negeri Raden Intan Lampung
}

\begin{tabular}{|c|c|}
\hline Article History & ABSTRACT \\
\hline $\begin{array}{l}\text { Received: } 25.03 .2019 \\
\text { Received in revised form: } \\
01.04 .2019 \\
\text { Accepted: } 10.04 .2019 \\
\text { Available online: } 05.08 .2019\end{array}$ & $\begin{array}{l}\text { DEVELOPMENT OF NARRATIVE COUNSELING INTERVENTION OF } \\
\text { DIGITAL-BASED IN RESPONDING TO THE CHALLENGE OF THE } \\
\text { INDUSTRIAL REVOLUTION ERA 4.0. The Industrial Revolution } 4.0 \text { now } \\
\text { provides changes that are fast and erratic in all aspects of life, including in the } \\
\text { field of education, especially in the field of guidance and counseling. This } \\
\text { condition brings opportunities as well as challenges, especially for the } \\
\text { millennial generation and for actors who have a role in education, especially in } \\
\text { the realm of guidance and counseling in the field in service delivery practices. } \\
\text { Narrative counseling is a postmodern counseling approach born of ideas in a } \\
\text { post-structuralist philosophy that is very coherent to answer conditions and } \\
\text { situations of uncertain change. The purpose of this study is to develop and find } \\
\text { out the development of digital-based narrative counseling in balancing changes } \\
\text { in the all-going to the digital era, which is now a center for militaries. The } \\
\text { method of research is using a qualitative approach to critical study methods. } \\
\text { The results show an effective process for narrative counseling services with } \\
\text { digitally based on every social media platform currently used by millennials. } \\
\text { KEYWORDS: Industrial Revolution, Narrative Counseling. }\end{array}$ \\
\hline
\end{tabular}

DOI: 10.30653/001.201933.100

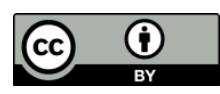

This is an open access article distributed under the terms of the Creative Commons Attribution 4.0 International License, which permits unrestricted use, distribution, and reproduction in any medium, provided the original work is properly cited. (c) 2019 Amdani Sarjun, Anisa Mawarni.

\section{PENDAHULUAN}

Era disrupsi menjadi hal yang menghantui berbagai kalangan seiring berkembangnya revolusi industri 4.0 yang kini tengah digaungkan dimana-mana. Revolusi industri kini membawa peluang sekaligus tantangan terutama bagi generasi milenial. Telaah mengenai revolusi industri 4.0, khusushnya istilah industri 4.0 berasal dari sebuah proyek yang diprakarsai oleh pemerintah Jerman untuk mempromosikan komputerisasi manufaktur. Schwab, Ekonom terkenal asal Jerman, pendiri dan ketua Eksekutif World Economic Forum (WEF) mengenalkan konsep Revolusi Industri 4.0 dalam bukunya yang berjudul "The Fourth Industrial Revolution". (Rosyadi, 2018: 1) menjelaskan 
adanya empat tahap revolusi industri, yakni industri 1.0, 2.0, 3.0, hingga industri 4.0. Fase industri merupakan suatu perubahan. Industri 1.0 ditandai dengan mekanisasi produksi untuk menunjang efektifitas dan efisiensi aktivitas manusia. Industri 2.0 ditandai oleh produksi massal dan standarisasi mutu, Industri 3.0 ditandai dengan penyesuaian massal dan fleksibilitas manufaktur berbasis otomatisasi dan robot. Industri 4.0 selanjutnya hadir menggantikan industri 3.0 yang ditandai dengan cyber fisik dan kolaborasi manufaktur (Hermann et al, 2015; Irianto, 2017 dalam Yahya, 2018, p. 2).

Revolusi industri di padang sebagai peluang karena berkembangnya teknologi informasi memberi kesempatan seluas-luasnya bagi setiap insan untuk mengakses informasi dalam hitungan detik bagi pengembangan ilmu pengetahuan dan perekonomian juga silaturahmi. Perkembanan ini membawa dampak positif sekaligus negatif (Triyono, 2018). Selain itu, teknologi informasi membawa tantangan antara lain diperlukannya kompetensi di bidang teknologi informasi, sebab semua aktivitas saat ini hampir seluruhnya dikendalikan dengan teknologi infomasi.

Perubahan merambah pada semua aspek kehidupan termasuk dalam bidang pendidikan, khususnya pada bidang bimbingan dan konseling. Era yang tidak bisa diprediksi atau bahasa yang kini sering dipakai adalah turbulence harus tetap mengarah pada perubahan yang lebih baik yang bukan hanya pada institusi tapi juga perubahan pada manusianya. Namun faktanya (Rahkmawati, 2017) menjabarkan bahwa perkembangan peradaban di Indonesia tidak linear, tetapi lebih berlangsung secara paralel. Pada masa sekarang peradaban masyarakat di Indonesia masih ada yang menunjukkan sikap primitif, agraris, industri 1.0, 2.0, dan 3.0. Salah satu penyebabnya adalah adanya masyarakat yang belum terjangkau internet tidak memahami internet dan tidak mau belajar menggunakan internet meskipun sebagian besar sikap primitif itu tidak menyentuh kaum milenial. Oleh karena itu berimplikasi terhadap perkembangan pelayanan pendidikan begitupun pada ranah bimbingan dan konseling. Kondisi ini akan berimplikasi terhadap peluang dan tantangan bagi siswa dan guru BK di era saat ini.

Menjawab tantangan era saat ini dapat dikembangkan proses layanan Bimbingan dan Konseling yang mampu mengikuti situasi dan kondisi era saat ini yang semuanya serba berbasis diginal dan online. Salah satu dari teknik layanan Bimbingan dan Konseling yang dapat digunakan adalah layanan konseling individual dan kelompok pendekatan post modern dengan teknik naratif. Layanan konseling naratif post modern adalah layanan yang menggunakan strategi dan teknik yang sesuai dengan perkembangan zaman, Layanan Konseling berorientasi postmodern ini telah terbukti dapat dilakukan dan dipergunakan untuk berbagai macam masalah (Geldard \& Geldard, 2012).

Pendekatan yang berkembang saat ini setelah era modern adalah digunakannya pendekatan postmodern. Pendekatan postmodern merupapakan pendekatan yang berlangsung singkat, umumnya antara empat sampai lima sesi saja dalam layanana konseling yang diberikan. Berfokus pada pemecahan masalah (solusi) yang menekankan pada sumber daya atau kompetensi dan kekuatan-kekuatan konseli, bukan berfokus pada penyebab atau problem (Corey, 2012). Pendekatan postmodern menekankan pada pandangan bahwa konseli adalah individu yang unik dan subjektif serta bahasa atau naratif yang dikonstruksikan sendiri oleh konseli, bukan menekankan pada realitas "objektif" realitas konsensual (realitas sebagaimana membangun bahasa, memelihara dan mengubah masing-masing tata pandang (worldview) individu. 
Pendekatan postmodern menjelaskan bahwa konselor menyediakan kesempatan bagi konseli untuk mendekonstruksi cerita dominan yang dibawa pada saat konseling. Konseli didorong untuk menuliskan kembali cerita tersebut dengan melihat masa lalu dan menuliskan kembali masa depan konseli (Corey, 2009, p. 307). Pemberian makna pribadi dan identitas naratif telah muncul sebagai topik utama dalam psikologi kepribadian dan kehidupan transisi untuk masa depan (Bauer \& McAdams, 2004; McAdams, 1993; Singer, 2004). Peran penting naratif dalam pemahaman individu secara global. Naratif dan diri individu tidak dapat dipisahkan dalam cerita secara bersamaan lahir dari pengalaman dan memberikan bentuk pemahaman. Kegiatan naratif memberikan kesempatan untuk membangun sistematika dalam peristiwa, dan untuk menciptakan kontinuitas antara masa lalu, saat ini, dan pandangan luas kedepan.

Dasar konseling naratif merupakan ide-ide dalam filsafat post strukturalis (Foucault, 1988; White, White, Wijaya, \& Epston, 1990; Combs \& Freedman, 2004; Lye, 2008; Thomas, 2004). Pada Post-struktural karya teori Michel Foucault, konseling naratif mendukung individu untuk secara kritis melihat kehidupan dan pengalaman Individu sebagai tertanam dalam konteks sosial, budaya, dan politik yang lebih besar. Sudut pandang ini, individu bekerja untuk memisahkan diri dari masalah (dikenal sebagai "eksternalisasi masalah"). kemudian dibuat untuk reauthoring alternatif cerita kehidupan yang disukai yang mampu digunakan untuk melawan masalah (White, White, Wijaya, \& Epston, 1990).

Pendekatan naratif merupakan respon terhadap pendekatan saintifik atau filosofis yang mengasumsikan bahwa manusia adalah makhluk yang logis dan membuat keputusan berdasarkan bukti, argumentasi yang lurus dan konsisten. Penelitian ini pendekatan naratif dalam prosesnya dilakukan dengan menggunakan basis digital pada semua platform online media sosial yang mungkin dapat digunakan oleh konseli atau anggota kelompok dalam layanan konseling kelompok yaitu seperti facebook, whatapp, email maupun messager. Basis digital yang digunakan tidak meninggalkan paradigma utama pada pendekatan nararif yang menganggap bahwa: 1) Manusia adalah makhluk yang berfikir berdasarkan keputusan yang rasional berlandaskan penalaran bukti dan diskusi yang ketat serta mendalam; 2) Setiap yang dianggap "rasional" ditentukan oleh pengetahuan dan pemahaman serta argumen- argumen, didiskusikan untuk membentuk suatu pemahaman; 3) Dunia adalah seperangkat teka-teki yang logis dan dapat dipecahkan melalui analisis yang rasional.

Acuan untuk merapat pada arah digital adalah acuan dari pemahaman bahwa dampak positif era disrupsi berdasarkan pendapat Setiawan (2017: 4) yakni: (a) Informasi yang dibutuhkan dapat lebih cepat dan lebih mudah dalam mengaksesnya. (b) Tumbuhnya inovasi dalam berbagai bidang yang berorientasi pada teknologi digital yang memudahkan proses dalam penyelesaian pekerjaan. (c) Munculnya media massa berbasis digital, khususnya media elektronik sebagai sumber pengetahuan dan informasi masyarakat. (d) Meningkatnya kualitas sumber daya manusia melalui pengembangan dan pemanfaatan teknologi informasi dan komunikasi. (e) Munculnya berbagai sumber belajar seperti perpustakaan online, media pembelajaran online, diskusi online yang dapat meningkatkan kualitas pendidikan. (f) Munculnya e-bisnis seperti toko online yang menyediakan berbagai barang kebutuhan dan memudahkan mendapatkannya. 


\section{METODE}

Penelitian ini menggunakan pendekatan kualitatif. Penelitian menggunakan model studi kritis design. Model penelitian ini berkembang dari teori kritis, feminis, ras dan pasca modern yang bertolak dari asumsi bahwa pengetahuan bersifat subjektif (Moleong, 2012). Penelitian ini dilakukan di salah satu SMA di Bandar Lampung.

Penelitian kritis memandang bahwa masyarakat terbentuk oleh orientasi kelas. Peneliti feniminis dan etnis memusatkan perhatiannya pada masalah-masalah gender dan ras, sedang peneliti pasca modern dan kritis memusatkan pada institusi social dan kemasyarakatan dan penelitian ini adalah penelitian pada pasca modern. Pada prosesnya dilakukan analisis naratif dari setiap proses dengan panduan observasi efektivitas layanan konseling kelompok.Penelitan kritis ini menggunakan kajian terhadap proses pelaksanaan konseling naratif dengan basis digital pada berbagai platform sosial media yang kini tengah digandrungi yang menjadi suatu fenomena pada era revolusi industri 4.0, dibuat dalam kajian yang bersifat mendalam yang berbeda dengan kajian eksperimental atau kajian lain yang bersifat generalisasi maupun pembandingan. Dalam penelitian kualitatif kritis ini fenomena revolusi industri 4.0 adalah satu kesatuan kasus atau fenomena yang diteliti secara mendalam dan utuh.

\section{HASIL DAN PEMBAHASAN}

Hasil penelitian diperoleh berupa proses konseling naratif berjalan dengan menggunakan platform sosial media yang digunakan sehari-hari oleh siswa. Proses penelitian melibatkan sebanyak 12 siswa melakukan proses pemahaman materi dan proses konseling kelompok dari evaluasi kriteria kepuasaan dalam proses layanan konseling kelompok yang telah dibuat. Didapat tingkat kemampuan terhadap pemahaman materi dan kepuasaan proses konseling naratif dalam bentuk kelompok melalui chat online pada beberapa platform sosial media menunjukan kepuasan dan proses layana konseling yang memenuhi semua kriteria yang seharusnya sesuai dengan acuan panduan pelaksanaan layanan Bimbingan dan Konseling, sementara pada proses layanan konvensional naratif dengan tatap muka seperti biasa tingkat pemahaman lebih rendah dan tingkat kepuasaan menunjukan pada prosesnya tidak memenuhi semua tahapan yang diharapkan karena minat siswa yang kurang. Sebelum pemberian layanan konseling kelompok dengan pendekatan naratif diperoleh nilai rata-rata skor siswa sebesar $31,2 \%$. Setelah diberikan layanan konseling kelompok pendekatan naratif berbasis digital dengan tanpa harus selalu bertatap muka namun dalam aplikasi platform sosial media yang dikehendaki dan mudah digunakan dan bahkan digunakan sehari-hari oleh siswa menjadi lebih intens proses konseling dalam prosesnya.

Setelah mendalami proses konselin kelompok dengan pendekatan naratif berbasis digital pada media sosial yang digunakan siswa dengan dibandingkan hasil pendalaman secara mendalam baik dalam proses dan sistematika dalam pelayanan kepada siswa penggunaan media digital menjadi magnet yang membuat siswa lebih merespon, komitmen dan konsisten mengikuti proses konseling. Artinya pemberian layanan konseling naratif berbasis digital pada berbagai platform sosial media pada menu chart memberikan layanan yang lebih efektif dan efesiean dalam pemberian layanan pada siswa kelas IX SMA Bandar Lampung Tahun Ajaran 2018/2019. 
Hasil yang efektif menunjukan kesesuaian dengan pemahaman generasi $Z$ yang kini dihadapi seperti yang telah dikatakan oleh Djiwandono (dalam Susana, 2012: 69) menyatakan bahwa generasi Z mempunyai kecenderungan gaya belajar aktif, global, sensing, dan visual. Pembelajar aktif mudah belajar dengan melakukan sendiri apa yang sedang dipelajari. Global berarti individu cenderung belajar dengan cara melompatlompat, menyerap materi secara random tanpa melihat keterkaitan antara yang satu dengan yang lain, dan tiba-tiba bisa mendapatkan sesuatu.

Selain itu juga di perkuat oleh Susana (2012: 57) generasi Z disebut juga Generation Net dengan ciri-ciri sebagai berikut: (a) memiliki akses yang cepat terhadap informasi dari berbagai sumber, (b) dapat mengerjakan beberapa hal dalam waktu bersamaan (multitasking), (c) lebih menyukai hal-hal yang bernuansa atau bernapaskan multimedia, (d) lebih menyukai berinteraksi melalui dunia maya, jejaring sosial (Facebook, Twitter, Yahoo Messenger) dan (e) dalam belajar, lebih menyukai hal-hal yang bersifat aplikatif dan menyenangkan.

Acuan inipun menjadi alasan penguat bahwa penggiat pendidikan khsussnya guru BK harus mampu mengikuti perubahan dengan mampu mengikuti arahan Kemenristekdikti (2018) karakteristik guru BK yang mampu mentransformasikan diri di era disrupsi sebagai berikut: (a) meningkatkan minat baca dan menambah koleksi buku; (b) mampu menjadi fasilitator, motivator dan inspirator; (c) mengunggah karya-karya tulisnya yang berkontribusi bagi upaya peningkatan kualitas layanan bimbingan dan konseling; (d) menerapkan pola hybrid learning (kombinasi tatap muka dan online) dan multitasking secara kreatif dan inovatif untuk meningkatkan kualitas layanan bimbingan dan konseling; dan (e) menerapkan pendekatan konstruktivistik berbasis ICT.

\section{SIMPULAN}

Penggunaan konseling naratif berbasis digital dalam pemberian layanan bimbingan konseling dapat lebih efektif dalam membantu guru BK menghadapi setiap permasalahan -permasalahan yang kini dialami pada siswa kelas XI SMA di Bandar Lampung. Saran dalam penelitian ini sebagai berikut: (1) Kepada guru BK di setiap sekolah hendaknya mau mengikuti perkembangan dan mendalami layanan berbasis digital (ICT). (2) Bagi peneliti selanjutnya wilayah penelitian selanjutnya perlu diperluas tidak hanya satu pendekatan yang digunakan namun dengan pendekatan lain dengan basis digital yang lebih kreatif dan inovatif.

\section{REFERENSI}

Azzaki, F. (2011). Perkembangan dunia konseling memasuki era grobalisasi. Pedagogi, 2, 255-262.

Bauer, J. J., \& McAdams, D. P. (2004). Personal growth in adults' stories of life transitions. Journal of Personality, 72(3), 573-602.

Brabender, V., \& Fallon, A. (2009). Group development in practice: guidance for clinicians and researchers on stages and dynamics of change. Washington, DC: American Psychological Association. 
Corey, G. (2009). Teori dan praktek dari konseling dan psikoterapi. Terjemahan oleh E. Koeswara. Jakarta: ERESCO Cumberland-Li.

Geldard, K., \& Geldard, D. (2011). Konseling remaja. Yogyakarta: Pustaka Pelajar.

Kemenristekdikti. (2018). Modul kompetensi pedagogik pendidikan profesi guru dalam jabatan tahun 2018. Jakarta: Kemenristekdikti.

McAdam, W. H. (1993). Heat transmission (3rd Edition). Tokyo: McGraw Hill Book Kogakusha.

Rakhmawati, D. (2017). Konselor sekolah abad 21: Tantangan dan peluang. Jurnal Konseling GUSJIGANG, 3(1), 58-63.

Rosyadi, S. (2018). Revolusi industri 4.0: Peluang dan tantangan bagi alumni universitas terbuka. Retrieved June 22, 2018, from https://www. researchgate. net/publication/revolusi-industri-40.

Setiawan, Wawan. (2017). Era Digital dan Tantangannya. Seminar Nasional Pendidikan Tahun 2017.

Sigelman, Carol, K., Shaffer, Devid R. ( 1995). Life-span Human Development California: Brooks/ Cole Publishing Company.

Susana, T. (2018). Kesetiaan pada panggilan di era digital. Jurnal Orientasi Baru, 21(1), 5578.

Triyono. (2017). Membangun karakter peserta didik tanpa hukuman dan permaafan. Surabaya: Seminar di STIKOSA AWS Surabaya.

Triyono. (2016). Sikap peduli kemaslahatan konselor sebagai modal upaya pengembangan karakter generasi muda Indonesia. In E. Purwanta et al (Eds.), Penguatan Orientasi Nilai dalam Bimbingan dan Konseling sebagai Upaya Pengembangan Karakter Generasi Muda Indonesia. Paper presented at Seminar Nasional BK, PPs UNY, 23 November 2016 (pp. 1-10). Yogyakarta: UNY.

White, M., White, M. K., Wijaya, M., \& Epston, D. (1990). Narrative means to therapeutic ends. New York: WW Norton \& Company.

Yahya, M. (2018). Era industri 4.0: Tantangan dan peluang perkembangan pendidikan kejuruan Indonesia. Pidato Pengukuhan Penerimaan Jabatan Profesor Tetap dalam Ilmu Pendidikan Kejuruan Fakultas Teknik Universitas Negeri Makassar pada tanggal 14 Maret 2018. Makassar: Universitas Negeri Makassar. 